\title{
Partisipasi Politik Masyarakat Dalam Pemilihan Walikota Jambi Periode Tahun 2018-2023 Di Kecamatan Telanaipura Kota Jambi
}

\author{
A Zarkasi ${ }^{1)}$, Dimas Rizal ${ }^{2)}$ \\ ${ }^{1}$ Fakultas Hukum, Universitas Jambi \\ ${ }^{2}$ Ilmu Politik, Universitas Jambi \\ 를.uasi.unja@gmail.com, ${ }^{2}$ dimas_rizalcr7@yahoo.com
}

\begin{abstract}
Abstrak. Pemilihan pemimpin secara langsung merupakan salah satu ciri khas dari demokrasi modern. Perubahan demokrasi ke arah yang lebih positif dapat dilihat dari keikutsertaan masyarakat dalam pemilihan kepala daerah. Oleh sebab itu, dalam upaya peningkatan partisipasi masyarakat harus adanya upaya yang serius dari para kandidat serta pelaksana dari pemilihan umum untuk menarik minat masyarakat untuk berpartisipasi dalam pemilihan umum. Karena salah satu tolok ukur dari keberhasilan demokrasi adalah sejauh mana masyarakat terlibat dalam proses politik yang ada. Keikutsertaan masyarakat dalam proses politik akan mencerminkan sejauh mana kualitas dan kapasitas dari masyarakat untuk terlibat dalam pengambilan kebijakan suatu pemerintahan. Semakin tinggi tingkat partisipasi maka akan semakin sedikit yang terlibat, berbanding terbalik dengan semakin rendah tingkat partisipasi masyarakatnya maka semakin banyak masyarakat yang terlibat. Penelitian ini menggunakan pendekatan kualitatif desktriptif. Sumber data yang di gunakan ini ada dua jenis yaitu sumber data primer dan data sekunder. Adapun Kesimpulan dari penelitian ini adalah Partisipasi politik masyarakat Kecamatan Telanaipura Kota Jambi dalam pemilihan walikota tahun 2018-2023 adanya penurunan dari pemilihan walikota sebelumnya pada periode 20132018.
\end{abstract}

Kata Kunci: Partisipasi Politik, Pemilihan Umum, Kota Jambi

\begin{abstract}
The direct election of leaders is one of the characteristics of modern democracy. Changes in democracy in a more positive direction can be seen from the people's participation in the regional head election. Therefore, in an effort to increase public participation there must be a serious effort by the candidates and the executor of the general election to attract the interest of the public to participate in the general election. Because one of the benchmarks of the success of democracy is the extent to which people are involved in the existing political process. Community participation in the political process will reflect the extent to which the quality and capacity of the community to be involved in policymaking in a government. The higher the level of participation, the less involved, inversely proportional to the lower level of community participation, the more people involved. This research uses a descriptive qualitative approach. Data sources used are of two types, namely primary data sources and secondary data. The conclusion of this study is the involvement of the community of Telanaipura Sub-district of Jambi City in the mayor election in 2018-2023 an increase from the mayor election period 2013-2018.
\end{abstract}

Keywords: Political Participation, Elections, Jambi City 


\section{PENDAHULUAN}

Negara Kesatuan Republik Indonesia adalah negara berkembang yang menganut sistem demokrasi. Salah satu indikator perkembangan demokrasi yaitu semakin terbukanya kesempatan bagi warga negara untuk terlibat dalam proses politik atau dikenal dengan partisipasi politik. Dalam sudut pandang politik, partisipasi politik masyarakat merupakan ciri khas modernisasi politik, disini kemajuan demokrasi dapat dilihat sampai seberapa besar partisipasi politik masyarakat disertakan (Samuel Huntington, 1994). Sehingga, partisipasi masyarakat dalam kehidupan politik merupakan prasyarat mutlak dalam sebuah tatanan negara yang demokratis. Hal ini didasari bahwa masyarakat memiliki peran yang sangat besar dalam penyelenggaraan demokrasi seperti halnya pemilihan umum. Oleh karena itu masyarakat tidak dapat dipisahkan dengan pemilihan umum karena merupakan satu kesatuan yang utuh dan menjadi faktor utama serta penentu berjalan suksesnya sebuah pelaksanaan pemilihan umum.

Partisipasi politik masih dianggap oleh masyarakat sebagai keikutsertaan dalam kegiatan pemilihan umum yaitu mencoblos di tempat pemungutan suara waktu pemilihan umum. Padahal jauh dari pada itu, partisipasi politik merupakan kegiatan sukarela dari warga masyarakat melalui mana mereka mengambil bagian dalam proses pemilihan pejabat publik, dan secara langsung atau tidak langsung, dalam proses pembentukan kebijakan umum. Hal ini dilihat terutama adalah tindakan yang bertujuan untuk mempengaruhi keputusan pemerintah, sekalipun fokus utamanya lebih luas tetapi abstrak, yaitu usaha untuk mempengaruhi alokasi nilai secara otoritatif untuk masyarakat (Miriam Budiardjo, 2014).

Pemilihan kepala daerah secara langsung diyakini memiliki kapasitas yang memadai untuk meningkatkan partisipasi politik masyarakat, sehingga masyarakat daerah memiliki kesempatan untuk memilih secara bebas calon pemimpin daerahnya tanpa adanya tekanan, intimidasi, kekerasan politik, maupun penekanan jalur birokrasi. Hal ini dapat dikatakan pemilihan kepala daerah secara langsung adalah momentum yang tepat munculnya berbagai varian preferensi pemilih yang menjadi faktor dominan dalam melakukan suatu tindakan atau prilaku politik dari masyarakat.

Oleh sebab itu, dalam upaya peningkatan partisipasi politik masyarakat harus berdasarkan pada analisis dan argumentasi yang kuat. Hal ini disebabkan adanya kebutuhan untuk membuat langkah strategis dalam peningkatan kuantitas dan kualitas partisipasi politik masyarakat dalam pemilihan umum serta penyempurnaan sistem pemilihan umum yang lebih baik kedepannya. Itu artinya argumentasi dan analisis yang timbul mesti berbasis pada metodologi atau kerangka pikir yang tepat untuk memahami dinamika partisipasi politik, serta didasari dengan kepekaan yang kuat terhadap dinamika politik yang berkembang dalam wilayah administratif, ekonomi, serta sosial budaya masyarakat.

Pemilihan kepala daerah secara serentak tahun 2018 digelar di 171 daerah di Indonesia, salah satu daerah yang mengikuti pemilihan kepala daerah secara serentak yaitu daerah Kota Jambi. Dari hasil rekapitulasi perhitungan jumlah DPT: 384.366, jumlah DPPh:708, jumlah pemilih DPTh:6.910, dengan jumlah total pemilih sebanyak 391.984. Dari hasil perhitungan suara pemilihan tingkat partisipasi masyarakat secara keselurahan 272.572 atau $69.53 \%$ (KPU Kota Jambi, 2018). Padahal target partisipasi masyarakat dalam politik nasional adalah sebesar $77,5 \%$, seharusnya masyarakat 
kota harus memiliki tingkat partisipasi politik yang tinggi.

Tingkat partisipasi masyarakat Kota Jambi pada pemilihan kepala daerah secara serentak pada tahun 2018 menimbulkan pertanyaan mendasar karena tidak bisa mencapai target nasional. Padahal kota jambi seharusnya menjadi parameter partisipasi politik masyarakat di Provinsi Jambi. Hal itu karena masyarakat kota jambi menjadi contoh dalam pemilihan di provinsi Jambi dimana masyarkatnya sangat berfikir logis terhadap pemilihan umum.

Berdasarkan uraian yang telah dipaparkan di atas, maka peneliti tertarik untuk mengkaji lebih mendalam, agar dapat diketahui secara jelas mengenai fenomena yang berkenaan dengan Partisipasi Politik Masyarakat Dalam Pemilihan Walikota dan wakil walikota Jambi Periode Tahun 2018-2023 di Kecamatan Telanaipura Kota Jambi.

\section{METODE PENELITIAN}

Metode Penelitian yang digunakan dalam penelitian ini adalah kualitatif. Penelitian kualitatif adalah penelitian yang berangkat dari perspektif fokus penelitian yang mengacu pada kualitas makna (Moleong: 2007). Metode pengumpulan data adalah penelitian kepustakaan yang didukung oleh media cetak seperti buku, majalah, surat kabar, jurnal, laporan dari berbagai sumber, dan juga media elektronik, terutama internet di mana data merupakan sumber sekunder. Selain data sekunder diatas penulis juga menggunakan data primer yang didapatkan dari wawancara bersama pihak yang kompeten dalam menjawab persoalan penelitian ini. Setelah didapatkan datanya, maka datadata diatas akan dianalisis dalam kerangka teoritis yang telah ditentukan untuk membuktikan bahwa hipotesis itu akurat dan akhirnya dapat menjawab pertanyaan penelitian. Data yang terkumpul dianalisis menggunakan analisis deskriptif untuk lebih mudah dalam menggambarkan Partisipasi Politik Masyarakat kota jambi dalam Pemilihan Walikota dan wakil walikota Jambi pada Periode Tahun 20182023. Untuk mensistematisasikan data yang dikumpulkan, analisis ini dilakukan melalui beberapa tahapan, yaitu: reduksi data, pemaparan data, deskripsi, dan verifikasi serta menarik kesimpulan.

\section{HASIL DAN PEMBAHASAN}

Pemilihan kepala daerah atau yang selanjutnya disebut (Pilkada) merupakan sarana bagi rakyat di daerah untuk melakukan aktivitas seleksi kepemimpinan secara langsung, umum, bebas, rahasia, jujur, dan adil. Dalam pemilihan kepala daerah rakyat berperan penuh untuk memilih siapa pemimpinnya, wakilnya yang layak untuk memimpin dan menduduki parlemen dalam struktur pemerintahan. Hal diatas telah diatur dalam Undang-Undang Nomor 7 Tahun 2017.

\section{Partisipasi Politik dalam Konteks Politik Elektoral}

Pada sistem demokrasi yang dianut di Negara Kesatuan Republik Indonesia, partisipasi politik merupakan bagian yang penting dalam dinamika politik Indonesia. Melalui partisipasi politik, warga masyarakat negara mempunyai haknya untuk terlibat aktif dalam proses politik praktis. Hal ini disebabkan karena sebagai warga negara mempunyai kebutuhankebutuhan tertentu yang memang menyangkut persoalan masyarakat secara menyeluruh. Oleh karena itu, untuk mewujudkan semua yang diatas tersebut. Maka sudah selayaknya masyarakat negara Indonesia berkontribusi langsung dalam proses elektoral. Baik itu dalam bentuk pemberian suara, melakukan diskusidiskusi mengenai politik, menghadiri kampanye, dan lain-lain. Dalam proses elektoral, salah satu indikator pemerintah untuk mengukur indeks keberhasilan pemilihan umum karena melihat pada tingkat partisipasi politik secara kuantitas. Dan mengetahui sejauh mana parameter keberhasilan tingkat kesadaran dalam partisipasi politik. Menurut Setiadi dan 
Kolip dalam Pengantar Sosiologi Politik (2013: 128-129), mengemukakan bahwa secara sederhana partisipasi politik dapat dipahami sebagai kegiatan seseorang atau kelompok orang untuk ikut serta secara aktif dalam kehidupan politik, yaitu dengan cara memilih langsung pemimpin dan wakilnya. Kegiatan ini mencakup tindakan seperti memberikan suara dalam pemilihan umum, menghadiri kampanye, diskusi politik, mengadakan komunikasi dengan pejabat pemerintah atau anggota parlemen, dan sebagainya. Oleh sebab itu, partisipasi politik merupakan kehendak sukarela masyarakat baik individu maupun kelompok.

Sementara itu, Herbert Miclosky dalam buku yang sama mengemukakan bahwa partisipasi politik adalah kegiatan-kegiatan sukarela dari warga masyarakat melalui mana mereka mengambil bagian dalam proses pemilihan penguasa, baik secara langsung atau tidak langsung, dalam proses pembentukan kebijakan umum. Selain itu, proses politik elektoral bukan hanya sebatas meningkatkan partisipasi politik secara kuantitas semata; untuk mencapai suatu pemilu yang ideal, maka masyarakat pun perlu diberikan wawasan akan pentingnya pendidikan politik (politic education). Dalam konteks proses politik elektoral biasanya selalu menampilkan drama-drama politik. Seperti adanya manajemen konflik (hoaks, isu-isu suku, agama, ras, dan antar golongan serta halhal lain) yang sengaja dibuat untuk mendelegitimasi kontestan atau pasangan lain. Maka dari itu diperlukan sebuah sistem yang baik untuk mewujudkan pemilu yang berkualitas dan berintegritas.

\section{Tipologi Partisipasi Politik}

A. Rahman H.I (2007: 288) menyatakan bahwa secara umum tipologi partisipasi sebagai kegiatan dibedakan menjadi: 1) Partisipasi aktif, yaitu partisipasi yang berorientasi pada proses input dan output. 2) Partisipasi pasif, yaitu partisipasi yang berorientasi hanya pada output, dalam arti hanya menaati peraturan pemerintah, menerima dan melaksanakan saja setiap keputusan pemerintah, 3). Golongan putih (golput) atau kelompok pemilih yang apatis, karena mengangap sistem politik yang ada menyimpang dari yang dicita-citakan.

Dengan demikian dapat dinyatakan bahwa orientasi partisipasi politik aktif terletak pada input dan output politik. Sedangkan partsipasi pasif terletak pada outputnya saja. Selain itu juga ada anggapan masyarakat dari sistem politik yang ada dinilai menyimpang dari apa yang dicita-citakan sehingga lebih menjurus kedalam partisipasi politik yang apatis. Pemberian suara dalam piwakot merupakan salah satu wujud partisipasi dalam politik yang terbiasa. Kegiatan ini walaupun hanya pemberian suara, namun juga menyangkut semboyan yang diberikan dalam kampanye, bekerja dalam membantu pemilihan, membantu tempat pemungutan suara dan lain-lain.

Partisipasi politik juga dapat dikategorikan berdasarkan jumlah pelaku yaitu individual dan kolektif.individual yakni seseorang yang menulis surat berisi tuntutan atau keluhan kepada pemerintah. Sedangkan yang dimaksud partisipasi kolektif ialah kegiatan warganegara secara serentak untuk mempengaruhi penguasa seperti kegiatan dalam proses pemilihan umum. Partisipasi kolektif dibedakan menjadi dua yakni partisipasi kolektif yang konvensional yang seperti melakukan kegiatan dalam proses pemilihan umum dan partisipasi politik kolektif nonkonvensional (agresif) seperti pemogokan yang tidak sah,melakukan hura-hura, menguasai bangunan umum. Partisipasi politik kolektif agresif dapat dibedakan menjadi dua yaitu aksi agresif yang kuat dan aksi agresif yang lemah. Suatu aksi agresif dikatakan kuat dilihat dari tiga ukuran yaitu bersifat anti rezim (melanggar peraturan mengenai aturan partisipasi politik normal), mengganggu fungsi pemerintahan dan harus merupakan kegiatan kelompok yang dilakukan oleh 
monoelit. Sedangkan, partisipasi politik kolektif agresif yang lemah adalah yang tidak memenuhi ketiga syarat tersebut diatas.

Di negara berkembang partisipasi politik cenderung digerakkan secara masif dan juga diarahkan untuk kepentingan pembangunan. Orang-orang yang melakukan demonstrasi atau memberikan suara dengan jalan tersebut tampaknya merupakan wujud nyata dari partisipasi politik yang mudah serta mengudang perhataian dari berbagai kalangan.

\section{Bentuk Partisipasi Politik}

Paige dalam Cholisin (2007:153) merujuk pada tinggi rendahnya kesadaran politik dan kepercayaan pemerintah (sistem politik menjadi empat tipe yaitu partisipasi aktif, partisipasi apatis, partisipasi militan radikal, dan partisipasi pasif. Partisipasi aktif, yaitu apabila seseorang memiliki kesadaran politik dan kepercayaan kepada pemerintah tinggi. Sebaliknya jika kesadaran politik dan kepercayaan kepada pemerintah rendah maka partisipasi politiknya cenderung pasif-tertekan (apatis). Partisipasi militan radikal terjadi apabila kesadaran politik tinggi tetapi kepercayaan kepada pemerintah sangat rendah. Dan apabila kesadaran politik sangat rendah tetapi kepercayaan terhadap pemerintah sangat tinggi maka partisipasi ini disebut tidak aktif (pasif).

Bentuk-bentuk partisipasi politik yang dikemukakan oleh Almond yang dikutip oleh Mohtar Mas'oed (2011:57-58) yang terbagai dalam dua bentuk yaitu partisipasi politik konvensional dan partisipasi politik non konvensional. Adapun rincian bentuk partisipasi politik konvensional dan non konvensional.

1). Partisipasi politik konvensional: Pemberian suara atau voting, Diskusi politik, Kegiatan kampanye, Membentuk dan bergabung dalam, kelompok kepentingan, Komunikasi individual dengan pejabat politik atau administratif. 2). Partisipasi politik nonkonvensional:
Pengajuan petisi, Berdemonstrasi, Konfrontasi, Mogok, Tindak kekerasan politik terhadap harta benda seperti: pengrusakan, pemboman, pembakaran, dan Tindakan kekerasan politik terhadap manusia: penculikan, pembunuhan, perang, revolusi.

\section{Pemilihan Walikota dan Wakil \\ Walikota Jambi Periode 2018-2023}

Dalam Pemilihan Kepala Daerah serentak tahun 2018, hampir sebagian besar daerah di Indonesia melakukan pemilihan, salah satunya adalah Kota Jambi. Pemilihan Walikota dan wakil walikota Jambi dilaksanakan pada tanggal 27 Juni 2018. Semua Calon Walikota dan Wakil Walikota Jambi diusulkan melalui Partai Politik atau gabungan Partai Politik sehingga mengahasilkan dua pasangan calon kandidat walikota dan wakil walikota jambi yang terdiri dari:

1) Pasangan Drs. H. Abdullah Sani, M.Pd.I dan Kemas Alfarizi Arsyad, S.E. Pasangan ini didukung 2 kekuatan besar yakni PDIP dan PAN. Dengan dukungan dari 2 partai ini, pasangan Abdullah dan Kemas berhasil mengantongi dukungan 11 kursi di DPRD Kota Jambi.

2) Pasangan Dr. H. Syarif Fasha, M.E dan Dr. dr. H. Maulana, M.KM. Pasangan ini didukung oleh 10 Partai diantaranya Partai Golkar, Demokrat, Gerindra, Hanura, PKB, PBB, PPP, PKPI dan Nasdem. Dengan perahu sebanyak itu, pasangan FashaMaulana berhasil mengantongi dukungan 34 kursi dari 45 kursi di DPRD Kota Jambi.

Pilkada tersebut menjadi suatu pertarungan yang sengit dikarenakan kedua pasangan calon tersebut adalah incumbent atau petahana yakni Syarif Fasha yang merupakan Walikota Kota Jambi periode 2013-2018 dan Abdullah Sani yang merupakan wakil dari Syarif Fasha. Berikut perolehan suara pasangan calon Walikota dan wakil Walikota Jambi pada Pilwako 2018: 
Gambar 1:

Perolehan Suara Pada Pilwako-

Wawako Jambi Periode 2018-2023

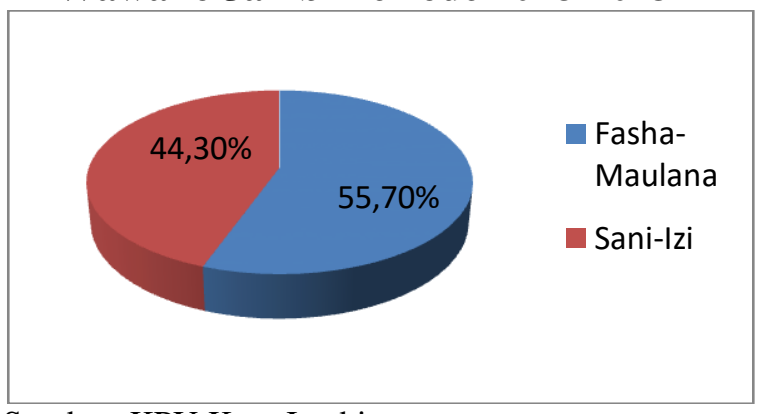

Sumber: KPU Kota Jambi

Dari gambar diatas dapat kita

ketahui, Syarif Fasha-Maulana berhasil memenangkan Pilwako dan Wawako Jambi untuk periode 2018-2023 dengan memperoleh $55,70 \%$ suara masyarakat kota jambi. Pada hari rabu tanggal 07 November 2018 pasangan Fasha-Maulana resmi dilantik oleh Plt Gubernur Provinsi Jambi Fachrori Umar di rumah dinas Gubernur Provinsi Jambi.

\section{Partisipasi Politik Masyarakat dalam Pemilihan Walikota dan Wakil Walikota Jambi di} Kec.Telanaipura tahun 2018.

Pemilihan Walikota Jambi pada Tahun 2018 menjadi sebuah fakta yang menarik untuk dilihat seberapa jauh tingkat partisipasi politk masyarakat dalam peristiwa politik tersebut. Karena Pilwakot menjadi salah satu indikator stabil dan dinamisnya demokratisasi di sebuah wilayah. Sementara pilwakot dianggap sebagai sebuah peristiwa periodik yang akan berlangsung, tetapi dalam pelaksanaannya selalu meninggalkan catatan penting tentang sejauh mana tingkat partisipasi masyarakatnya.

Berbicara tentang Pilwakot maka agenda sejatinya adalah bagaimana bangsa ini kedepannya tidak melepaskan dari upaya penguatan partisipasi dan kemandirian rakyat melalui proses yang demokratis. Hal ini merupakan catatan penting mengingat karakter dan kemampuan demokrasi rakyat masih terlalu rendah, sementara dalam tataran lapangan dan pelaksanaannya, rakyat hidup dalam ruang yang sangat terbuka akan informasi.

Hal yang sebenarnya sangat paradox dengan kondisi masyarakat yang belum diiringi dengan mental yang cukup siap dalam berdemokrasi. Kebebasan politik yang terus 'menggema' tidak didukung oleh sebuah pemikiran rasional, daya kritis dan kemandirian bersikap ditengah masyarakat. Padahal nilai ini adalah modal utama yang diusung dalam kerangka demokrasi yang turut pula mengusung terbukanya ruang-ruang politik.

Kebebasan yang tidak didasari pada sebuah pemikiran kritis dan rasionalitas politik, pada akhirnya akan menjadikan masyarakat hanya sebagai alat penguatan kekuasaan para elite politik di Indonesia. Upaya penguatan dan perebutan kekuasaan semata pada aras politik lokal akan mengundang konflik politik perebutan kekuatan dan akan terus meningkat seiring dilaksanakannya mekanisme pemilihan kepala daerah secara langsung. Dalam sebuah kondisi belum menguatnya kesadaran dalam berpolitik di tingkatan masyarakat luas, maka momentum pemilu menjadi pertarungan politik yang kian terbuka dan membuka ruang potensi manipulasi, konflik, politik uang, dan intimidasi politik.

Dari hasil penelitian ditemukan bahwa dalam tingkat partisipasi politik masyarakat kota jambi dalam pemilihan walikota dan wakil walikota jambi ada pergesaran menuju lebih baik dibandingkan dengan pilwakot pada periode sebelumnya. Pada pilwakot 2013 partisipasi politik masyarakat kota jambi berjumlah 249.848 (60.19\%) dari 415.068 Suara yang terdaftar di DPT. Sedangkan pada Pilwakot Jambi 2018 Partisipasi Poltik Masyarakat Kota Jambi berjumlah 272.572 (69.54\%) dari 391.984 suara yang terdaftar. (Data KPU Kota Jambi).

Namun, dalam konteks partisipasi politik masyarakat di kecamatan 
Jurnal Ilmu Sosial dan Pendidikan

http://ejournal.mandalanursa.org/index.php/JISIP/index

Terakreditasi Peringkat 5 (No. SK: 85/M/KPT/2020)
Vol. 4. No. 3 Juli 2020

p-ISSN: 2598-9944 e-ISSN: 2656-6753 telanaipura dalam pilwakot 2018 mengalamai penurunan dari pilwakot sebelumnya pada 2013. Pada pilwakot 2013 jumlah partisipasi politik masyarakat kecamatan telanaipura mencapai 29.650 suara. Sedangkan pada pilwakot jambi 2018 di kecamatan telanaipura hanya 21.443 suara. Ini menunjukkan bahwa partisipasi politik masyarakat kecamatan telanaipura mengalami penurunan.

\section{Gambar 2:}

Partisipasi Politik Perkecamatan pada Pilwakot Jambi 2018

\begin{tabular}{|c|c|c|c|}
\hline Kecamatan & Sani-|zi & Fasha-Maulana & Suara sah \\
\hline Alam Barajo & $17.581(42,31 \%)$ & $23.967(57,69 \%)$ & 41.548 \\
\hline Danau Sipin & $8.086(39,30 \%)$ & $12.485(60,70 \%)$ & 20.571 \\
\hline Danau Teluk & $2.358(33,76 \%)$ & $4.625(66,24 \%)$ & 6.983 \\
\hline Jambi Selatan & $12.724(48,68 \%)$ & $13.411(51,32 \%)$ & 26.135 \\
\hline Jambi Timur & $14.721(46,47 \%)$ & $16.951(53,53 \%)$ & 31.672 \\
\hline Jelutung & $12.842(46,17 \%)$ & $14.972(53,83 \%)$ & 27.814 \\
\hline Kota Baru & $13.600(42,20 \%)$ & $18.625(57,80 \%)$ & 32.225 \\
\hline Paal Merah & $22.577(50,53 \%)$ & $22.096(49,47 \%)$ & 44.673 \\
\hline Pasar Jambi & $2.335(45,34 \%)$ & $2.814(54,66 \%)$ & 5.149 \\
\hline Pelayangan & $2.297(33,41 \%)$ & $4.577(66,59 \%)$ & 6.874 \\
\hline Telanaipura & $8.314(38,77 \%)$ & $13.129(61,23 \%)$ & 21.443 \\
\hline Total & $117.435(44,30 \%)$ & $147.652(55,70 \%)$ & 265.087 \\
\hline
\end{tabular}

Sumber: Wikidipedia Pilwakot Jambi 2018

Dari gambar diatas kita bisa melihat bahwasahnya partisipasi politik masyarakat kota jambi dalam pemilihan walikota dan wakil walikota jambi sedikit bergerak kearah yang lebih baik, namun sebaliknya pada kecamatan telanaipura tingkat partisipasi politik masyarakat dalam pilwakot jambi 2018 mengalami penurunan dari pilwakot sebelumnya pada tahun 2013. Ada beberapa faktor yang mempengaruhi tingkat partisipasi politik masyarakat dalam pilkada.

1. Peran Media Massa

$$
\text { Peran media Massa dalam }
$$
demokrasi sangat penting. Media diharapkan dapat menjalankan fungsi tidak hanya sebagai sumber informasi namun juga diharapkan dapat menjadi sarana dalam pendidikan politik. Isi media dalam memberikan informasi secara luas mengenai Pilwakot Jambi juga mendorong terciptanya kesadaran seluruh masyarakat kota jambi khususnya masyarakat telanaipura untuk berpartisipasi dalam pilwakot Jambi 2018. Sebaliknya jika media massa rendah intensitasnya dalam memberitakan informasi politik, khususnya informasi tentang penyelenggaraan Pilwakot kota jambi dapat mendorong rendahnya juga partisipasi politik masyarakat.

2. Kinerja KPUD

Kinerja KPUD juga merupakan Salah satu faktor penting dalam mendorong tingginya partisipasi politik masyarakat pada Pilwakot Jambi pada tahun 2018. Penataan daftar pemilih tetap (DPT) yang baik sangat mendukung tingginya partisipasi politik. Sementara persoalan ini sering menjadi masalah selama pelaksanaan Pemilu karena banyaknya warga yang sering tidak terdaftar sehingga menjadi sebuah permasalahan krusial yang tidak mendapatkan solusi. Sebaliknya tanpa adanya kerja yang baik dari KPUD maka partisipasi masyarakat juga akan berdampak.

3. Peran dari pasangan calon

Peran dari para calon juga menjadi Faktor yang sangat berpengaruh pada tingginya tingkat partisipasi politik masyarakat pada setiap pemilu. Kecamatan telanaipura menjadi pusat perhatian bagi semua kecamatan yang ada di kota jambi, dikarenakan posisinya yang sangat strategi dimana pusat politik dan pemerintahan provinsi jambi berada di kecamatan telanaipura. Sehingga semua cawako jambi memusatkan pada masyarakat kecamatan telanaipura. Berbagai macam cara dan strategi dilakukan oleh semua tim pemenangan kandidat walikota jambi.

4. Faktor Sosial dan budaya

Faktor terakhir yang juga sangat mempengaruhi pada tingkat partisipasi politik adalah faktor sosial dan budaya. Pragmatisme merupakan sebuah budaya yang cukup subur tumbuh di negara ini. Ini 
berdasarkan beberapa literatur dan penelitian yang pernah ada dan sudah dilakukan oleh beberapa peneliti, menunjukan fakta bahwa pragmatisme masyarakat dalam mengikuti pemilu sangat besar. Dan bisa dipastikan budaya tersebut memang sudah menjadi adat istiadat atau kebiasaan yang berkembang sudah cukup lama ditengah masyarakat.

Kecamatan telanaipura yang merupakan kecamatan yang terletak di pusat pemerintahan provinsi jambi tidak lepas dari budaya pragmatisme. Beberapa masyarakat telanaipura yang coba penulis wawancarai mengenai politik uang (Money Politic) hampir semuanya mengakui bahkan merasakan langsung dampak dari praktek politik uang yang terjadi pada pilwakot jambi 2018.

Demikianlah beberapa faktor yang sangat memperngaruhi tinggi dan rendahnya partisipasi politik masyarakat dalam setiap pemilu, khususnya pilwakot jambi di kecamatan telanaipura Kota Jambi 2018.

\section{KESIMPULAN}

Berdasarkan pembahasan yang telah dikemukakan di atas, maka penelitian ini dapat disimpulkan bahwa partisipasi politik masyarakat pada pemilihan walikota dan wakil walikota jambi pada tahun 2018 semakin membaik. Namun sebaliknya pada tingkat Kecamatan Telanaipura, mengalami penurunan dari jumlah partisipasi politik masyarakat dalam pemilihan walikota dan wakil walikota jambi dari sebelumya yaitu pada tahun 2013.

Kemudian faktor-faktor yang
sangat mempengaruhi tinggi dan
rendahnya partisipasi politik pada
masyarakat dalam pemilihan kepala daerah
(pilkada) adalah media massa, peran
KPUD, Peran dari para calon, dan yang
terakhir faktor sosial dan budaya. Semua
faktor itu merupakan hasil dari
pengamatan peneliti, sehingga peneliti
mengambil kesimpulan mengapa
partisipasi politik masyarakat di

kecamatan telanaipura rmengalami kemunduran pada pilwakot jambi tahun 2018, hal itu disebabkan oleh faktor-faktor diatas.

\section{DAFTAR PUSTAKA}

A, Rahman, H.I. 2007. Sistem Politik Indonesia. Graha Ilmu: Yogyakarta.

Budiarjo, Miriam. 2009. Dasar-dasar Ilmu Politik. Jakarta, PT. Gramedia Pustaka Bandung.

Cholisin, dkk. 2007. Dasar-Dasar Ilmu Politik. Yogyakarta: UNY Press.

Huntington, Samuel P. 1984. Partisipasi Politik Di Negara Berkembang. Jakarta, Sangkar Pulsar.

KPUD Kota Jambi, Hasil Pilwakot Jambi Periode 2018-2023

Maleong, J. Lexy. Metodologi Penelitian Kualitatif. Bandung. PT Remaja Rosdakarya, 2004.

Mas'oed, Mochtar. (2011). Perbandingan Sistem Politik. Yogyakarta: Gadjah Mada University

Michael, Rush, Althof, Philip. 2005. Pengantar Sosiologi Politik. Jakarta, Rajawali Pers

Miles, Matthew B, dan Huberman. 1992. Analisis Data Kualitatif. Jakarta, Universitas Indonesia Press.

Ranjabar,Jacobus. 2016. Pengantar Ilmu Politik. Bandung, Alfabeta.

Surbakti, Ramlan. 1992. Memahami Ilmu Politik. Jakarta, PT. Gramedia Widiasarana Indonesia.

Setiadi, M, Kolip. 2013. Pengantar Sosiologi. Jakarta, Kencana.

Undang-Undang (UU) Nomor 7 tahun 2017 tentang Pemilihan Umum (Pemilu).

Syahrial, Sarbaini, dkk. 2011. Pengetahuan Dasar Ilmu Politik. Bogor, Ghalia Indonesia. 